\section{Jurnal TAUJIH}

Jurnal Pendidikan Islam

Vol. 14 No. 01 Januari-Juni 2021

P-ISSN : 2085-7934
Program Studi

Pendidikan Agama Islam

IAI Al-Qur'an Al-Ittifaqiah Indralaya

E-ISSN : 2774-7379

\title{
PENDIDIKAN MODERASI BERAGAMA SEBAGAI PERISAI RADIKALISME DI LEMBAGA PENDIDIKAN
}

\author{
Umar Al Faruq ${ }^{1}$ dan Dwi Noviani ${ }^{2}$ \\ ${ }^{1}$ UIN Maulana Malik Ibrahim Malang Jawa Timur, \\ ${ }^{2}$ IAI Al-Qur'an Al-Ittifaqiah Indralaya Ogan Ilir Sumatera Selatan \\ e-mail: ${ }^{1}$ mazalfa2018@gmail.com, ${ }^{2}$ dwi.noviani83@yahoo.co.id
}

\begin{abstract}
Acts of radicalism in Indonesia lately tend to increase. Ironically, this often contradicts the failure of religious education in shaping moderate attitudes and behavior. This study will discuss religious moderation education as a protector of radicalism in educational institutions. This research uses a descriptive approach with the type of case study research at SMA Selamat Pagi Indonesia Batu. The results showed that the implementation of religious moderation education at SMA SPI Batu was able to shape moderate attitudes and behavior of students so that radicalism could grow and develop in the institution. Meanwhile, the process of religious moderation education at the institution is carried out through an integration system between schools, dormitories, and Kampung Kids (KD).
\end{abstract}

Keywords: Education, Religious Moderation, Shield, Radicalism

Umar Al Faruq dan Dwi Noviani: Pendidikan Moderasi Beragama Sebagai Perisai 


\section{Jurnal TAUJIH \\ Jurnal Pendidikan Islam}

Vol. 14 No. 01 Januari-Juni 2021

P-ISSN : 2085-7934
Program Studi

Pendidikan Agama Islam

IAI Al-Qur'an Al-Ittifaqiah Indralaya

E-ISSN : 2774-7379

\begin{abstract}
Abstrak
Tindak radikalisme di Indonesia belakangan ini cenderung mengalami peningkatan. Ironisnya, hal tersebut sering dikaitkan dengan kegagalan pendidikan agama dalam membentuk sikap dan perilaku moderat. Penelitian ini akan membahas tentang pendidikan moderasi beragama sebagai perisai radikalisme di lembaga pendidikan. Penelitian ini menggunakan pendekatan kualitatif deskriptif dengan jenis penelitian studi kasus di SMA Selamat Pagi Indonesia Batu. Hasil penelitian menunjukkan bahwa implementasi pendidikan moderasi beragama di SMA SPI Batu mampu membentuk sikap dan perilaku moderat peserta didik sehingga paham radikalisme dapat dicegah untuk tumbuh dan berkembang di lembaga tersebut. Adapun, proses pendidikan moderasi beragama di lembaga tersebut dilakukan melalui sistem integrasi antara sekolah, asrama, dan Kampung Kids (KD).
\end{abstract}

Kata kunci: Pendidikan, Moderasi Beragama, Perisai, Radikalisme 


\section{Jurnal TAUJIH Jurnal Pendidikan Islam}

Vol. 14 No. 01 Januari-Juni 2021

P-ISSN : 2085-7934

\section{Program Studi \\ Pendidikan Agama Islam}

IAI Al-Qur'an Al-Ittifaqiah Indralaya

E-ISSN : 2774-7379

\section{Pendahuluan}

Dunia pendidikan di Indonesia dalam kurun terakhir mendapat sorotan tajam dari berbagai kalangan. Berbagai media memberitakan tentang aksi radikalisme dan intoleransi yang cenderung mengalami peningkatan. Hal tersebut berdasarkan pada hasil survey yang dirilis oleh Wahid Institut bahwa radikalisme mengalami peninngkatan di tengah masyarakat. Sebanyak 600 ribu dari total 150 juta jiwa orang yang disurvey terpapar radikalisme. Pada sisi lain, terjadi peningkatan aksi intoleransi $46 \%$ menjadi $54 \%$ atau meningkat $8 \%{ }^{1}$. Sedangkan survey PPIM merilis hasil bahwa peningkatan radikalisme justru kebanyakan terjadi di lembaga pendidikan seperti sekolah dan perguruan tinggi. Irnisnya, ternyata tindakan tersebut tidak hanya dilakukan oleh para peserta didik, akan tetapi juga dilakukan oleh para guru dan dosen agama ${ }^{2}$.

Sementara itu, Undang-Undang Sisdiknas tahun 2003 menjelaskan bahwa pendidikan agama di Indonesia harus mampu mengantarkan peserta didik untuk memiliki kecerdasan kognitif terkait pengetahuan keagamaan dan berbudi luhur. Pesan undang-undang tersebut menyiratkan bahwa dalam pendidikan agama seharusnya mampu mengantarkan peserta didik untuk memiliki sikap dan perilaku yang mencerminkan nilai-nilai agama yaitu kasih sayang, kedamaian, toleransi, dan kelembutan. Pendidikan agama tidak hanya mengandung ajaran agar seorang hamba bermuamalah dengan baik kepada sang pencipta (Tuhan) yaitu hablu minallah, akan tetapi lebih dari itu manusia adalah mahluk sosial yang juga harus mampu bermuamalah dengan sesama atau hablu minannas. Keduanya, baik secara vertikal maupun horizontal harus seimbang, karena diantara manifestasi ibadah adalah berbuat baik antarsesama manusia dan alam semesta

Secara kedudukan, pendidikan agama di Indonesia memiliki posisi yang strategis di dalam sistem pendidikan nasional. Hal tersebut dikarenakan pendidikan agama memiliki legalitas formal sebagai mata pelajaran yang wajib untuk diajarkan kepada semua peserta didik di seluruh jenjang pendidikan dari SD/MI sampai perguruan tinggi ${ }^{3}$. Pendidikan agama

1 TimRed MI, "Survei Wahid Institute: Intoleransi-Radikalisme Cenderung Naik," 18 Januari, 2020, https://mediaindonesia.com/read/detail/284269-survei-wahid-institute-intoleransi-radikalisme-cenderung-naik.

${ }^{2}$ Addi M Idhom and Terry Muthahhari, "Survei \{UIN\} Jakarta: Intoleransi Tumbuh Di Banyak Sekolah Dan Kampus - \{Tirto.ID\}," Tirto.Id (Tirto.id, 2017); PPIM UIN Jakarta, "Survei PPIM 2018: Menyibak Intoleransi Dan Radikalisme Guru," Ppim.Uinjkt.Ac.Id, 2018, https://conveyindonesia.com/survei-ppim-2018-menyibakintoleransi-dan-radikalisme-guru/; PPIM UIN Jakarta, "Survei PPIM_ 58 Persen Siswa Berpandangan Radikal," 2020.

Anonimus, "Undang-Undang Sistem Pendidikan Nasional," Acta Padiatrica, 2003, https://doi.org/10.1111/j.1651-2227.1982.tb08455.x; Umar Al Faruq, "Politik Dan Kebijakan Tentang Majelis Taklim Di Indonesia (Analisis Kebijakan Peraturan Menteri Agama No 29 Tahun 2019)," AL MURABBI: Jurnal Umar Al Faruq dan Dwi Noviani: Pendidikan Moderasi Beragama Sebagai Perisai Radikalisme di Lembaga Pendidikan. 


\section{Jurnal TAUJIH Jurnal Pendidikan Islam}

Vol. 14 No. 01 Januari-Juni 2021

P-ISSN : 2085-7934

\section{Program Studi \\ Pendidikan Agama Islam}

IAI Al-Qur'an Al-Ittifaqiah Indralaya

E-ISSN : 2774-7379

diharapkan mampu menjadikan peserta didik pribadi yang berbudi luhur, berperilaku santun dan ramah, inklusif, toleran, moderat yang tidak ektrem kanan (radikal) atau ekstrem kiri (liberal) sebagaimana pesan yang ada di dalam ajaran agama.

Namun, fakta yang ada di lapangan masih jauh dari harapan. Masih banyak ditemukan penyimpangan moral akibat sikap dan perilaku yang mengarah kepada radikalisme yang dilakukan oleh para peserta didik baik di lingkungan sekolah dan di masyarakat ${ }^{4}$. Sikap atau perilaku intoleran dan radikal tersebut pada dasarnya sangat bertentangan sekali dengan nilainilai ajaran agama yang sangat menjunjung tinggi pluralitas. Akibatnya, tidak sedikit dampak dari perilaku tersebut berbuntut menjadi konflik sosial keagamaan yang berujung pada tindak kekerasan fisik dan non-fisik. Pendidikan agama yang seharusnya dapat menjadikan peserta didik menjadi pribadi yang santun ternyata masih jauh dari harapan. Nilai-nilai agama yang luhur seperti kasih sayang dan toleransi belum mampu dipahami, dihayati, dimaknai, dan diimplementasikan di dalam perilaku peserta didik sehari hari.

Sementara dalam tataran praktis, pendidikan agama masih seringkali hanya menyasar ranah kognitif yang mengajarkan pengetahuan semata atau bersifat informatif dan cenderung mengabaikan ranah afektif dan psikomotorik. Akibatnya, peserta didik hanya unggul di dalam pemahaman materi agama, tapi mereka masih sangat lemah dalam memaknai setiap ajaran agama yang diperoleh sehingga belum mampu menerapkannya di dalam perilaku mereka sehari hari ${ }^{5}$.

Realita di atas mengindikasikan bahwa masih terdapat masalah atau kelemahan di dalam praktik pendidikan agama terutama dalam menanamkan nilai-nilai agama seperti toleransi dan kasih sayang. Akibatnya, tidak sedikit para peserta didik tidak mampu memahami dan memaknai nilai-nilai ajaran agama yang luhur tersebut sehingga seringkali mereka menjadikan agama

Pendidikan Agama Islam 1, no. 1 (2020): 41-59; Umar Al Faruq, "Peluang Dan Tantangan Pendidikan Muhammadiyah Di Era 4.0," Ar-Risalah: Media Keislaman, Pendidikan Dan Hukum Islam XVIII, no. 1 (2020): 1330; Sukring, "Kedudukan Pendidikan Agama (Islam) Dalam Undang-Undang No. 20 Tahun 2003 Tentang Sisdiknas,” Jurnal Hukum “LEGITIME” III, no. 1 (2013).

${ }^{4}$ Sitti Aminah, "Peran Pemerintah Menanggulangi Radikalisme Dan Terorisme Di Indonesia," JURNAL KELITBANGAN 04, no. 01 (2016): 41; Muhammad Saekan Muchith, "Radikalisme Dalam Dunia Pendidikan," Addin 10, no. 1 (2016): 163, https://doi.org/10.21043/addin.v10i1.1133; Zuly Qodir, "Muhammadiyah Memperkuat Moderasi Islam Memutus Radikalisme," Maarif 14, no. 2 (2019): 12-29.

5 Faridi, Model Pendidikan Karakter Berbasis Nilai-Nilai Rabbani, Pertama (Malang: Baskara Media Aditya Media Group, 2020); Selviyanti Kaawoan, "Pendidikan Agama Islam Dalam Membentuk Perilaku Toleran Pada Warga Sekolah," Manajement Pendidikan Islam, 2014; Sirajuddin Saleh, "Peran Lembaga Pendidikan Dalam Membentuk Karakter Bangsa," in Seminar Nasioonal Pendidikan Ilmu-Ilmu Sosial Membentuk Karakter Bangsa Dalam Rangka Daya Saing Global (Makassar: HISPISI, 2016), 101-12. 


\section{Jurnal TAUJIH Jurnal Pendidikan Islam}

Vol. 14 No. 01 Januari-Juni 2021

P-ISSN : 2085-7934

\section{Program Studi \\ Pendidikan Agama Islam}

IAI Al-Qur'an Al-Ittifaqiah Indralaya

E-ISSN : 2774-7379

sebagai klaim kebenaran terhadap agama lain serta alat untuk menjustifikasi kesalahan atau kesesatan kelompok tertentu. Oleh karenanya, dibutuhkan satu konsep pendidikan agama yang mampu membentuk perilaku keagamaan yang moderat dan toleran. Di dalam hal ini, pendidikan moderasi beragama disinyalir sebagai suatu konsep pendidikan agama yang mampu membentuk karakter peserta didik untuk berperilaku keagamaan yang inklusif dan toleran serta tidak ekstrem 6

Pendidikan moderasi beragama sudah banyak diterapkan di berbagai lembaga pendidikan baik formal maupun non-formal. Bahkan, dalam praktik pembelajarannya, moderasi beragama telah banyak mengalami perkembangan. Beberapa penelitian yang fokus pada implementasi dan pengembangan pendidikan moderasi beragama di lembaga pendidikan menunjukkan hasil positif bahwa konsep moderasi beragama mampu meningkatkan kesadaran peserta didik untuk bersikap dan berperilaku moderat ${ }^{7}$.

SMA Selamat Pagi Indonesia Batu adalah salah satu sekolah umum yang menerapkan konsep pendidikan moderasi beragama. SMA SPI Batu adalah lembaga pendidikan formal di Indonesia yang para peserta didiknya berlatar belakang multikultural. Sekolah tersebut adalah salah satu lembaga pendidikan di Indonesia yang menerapkan konsep pendidikan moderasi beragama kepada peserta didiknya agar mereka dapat menerima segala bentuk perbedaan sehingga mampu berperilaku moderat dan toleran. Penelitian ini akan membahas tentang implementasi pendidikan moderasi beragama di SMA Selamat Pagi Indonesia Batu sebagai perisai radikalisme di lembaga pendidikan.

${ }^{6}$ Ahmad Zainuri Mohamad Fahri, “Moderasi Beragama Di Indonesia,” Jurnal.Radenfatah.Ac.Id 25, no. 2 (2019), http://jurnal.radenfatah.ac.id/index.php/intizar/article/view/5640; Khoirul Qolbi Insan, "LHS Dan Moderasi Beragama," Direktorat Jenderal Pendidikan Islam Kementerian Agama RI, 2019; M. Quraish Shihab, Wasathiyyah: Wawasan Islam Tentang Moderasi Beragama, I (Jakarta: Lentera Hati, 2019); Mohd Shukri Hanapi, "The Wasatiyyah (Moderation) Concept in Islamic Epistemology: A Case Study of Its Implementation in Malaysia," International Journal of Humanities and Social Science 4, no. 9(1) (2014): 51-62.

7 Ta'rif Asror Baisuki, "Penanaman Karakter Moderat Di Ma'had 'Aly Situbondo," Edukasi: Jurnal Penelitian Pendidikan Agama Dan Keagamaan 15, no. 3 (2017): 459-70; Edy Sutrisno, “Aktualisasi Moderasi Beragama Di Lembaga Pendidikan," Jurnal Bimas Islam 12, no. 1 (2019); Yedi Purwanto et al., "Internalisasi Nilai Moderasi Melalui Pendidikan Agama Islam Di Perguruan Tinggi Umum," EDUKASI: Jurnal Penelitian Pendidikan Agama Dan Keagamaan, 2019, https://doi.org/10.32729/edukasi.v17i2.605; M. A. Hermawan, "Nilai Moderasi Islam Dan Internalisasinya Di Sekolah,” Insania: Jurnal Pemikiran Alternatif Kependidikan 25, no. 1 (2020): 3143; Hani Hiqmatunnisa and Ashif Az Zafi, "Penerapan Nilai-Nilai Moderasi Islam Dalam Pembelajaran Fiqih Di Ptkin Menggunakan Konsep Problem-Based Learning,” JIPIS 29, no. 1 (2020): 27-35. 


\section{Jurnal TAUJIH \\ Jurnal Pendidikan Islam}

Vol. 14 No. 01 Januari-Juni 2021

P-ISSN : 2085-7934

\section{Program Studi \\ Pendidikan Agama Islam \\ IAI Al-Qur'an Al-Ittifaqiah Indralaya \\ E-ISSN : 2774-7379}

\section{Metode penelitian}

Penelitian ini menggunakan pendekatan kualitatif yaitu penelitian yang berusaha untuk memotret fenomena yang ada dengan cara mendeskripsikan setiap hal yang menjadi fokus penelitian. Adapun jenis penelitian yang digunakan di dalam penelitian ini adalah field research atau studi lapangan di SMA Selamat Pagi Indonesia Batu. Sedangkan teknik pengumpulan data diperoleh melalui tiga cara yaitu: pertama, observasi dengan cara datang atau terjun langsung ke lapangan untuk mengamati realita fenomena yang terjadi; kedua, wawancara mendalam dan terbuka secara daring (online) dengan siswa SMA SPI Batu dan guru agama; ketiga, studi dokumen dengan cara menelaah beberapa dokumen sekolah seperi jurnal, majalah dan lainnya yang terkait dengan penelitian. Selanjutnya, data dianalisa secara mendalam dengan menggunakan teknik analisa data melalui kondensasi data, display data, dan verifikasi data ${ }^{8}$. Untuk mengukur kevalidan data, peneliti menggunakan triangulasi sumber data dengan cara mengkorelasikan data yang diperoleh dari beberapa sumber data sebagaimana yang dipaparkan pada teknik pemerolehan data. Analisa data dilakukan secara jujur tanpa ada unsur keberpihakan sebagaimana prinsip yang terdapat di dalam penelitian kualitatif ${ }^{9}$.

\section{Hasil dan Pembahasan}

\section{A. Konsep Moderasi Beragama}

Secara bahasa, moderasi berasal dari bahasa Latin moderatio yang bermakna sedang-sedang saja yaitu tidak berlebihan dan tidak kekurangan, Di dalam KBBI, moderasi diartikan sebagai pengurangan kekerasan dan penghindaran ekstreminitas ${ }^{10}$. Moderasi dikaitkan dengan sikap atau perilaku untuk tidak ekstrem baik ekstrem kanan (radikal) maupun ekstrem kiri (liberal). Moderasi adalah memilih di antara keduanya yaitu berada di tengah. Oleh karenanya, seseorang yang memposisikan diri di tengah dan tidak memihak salah satu sayap baik kanan maupun kiri diistilahkan dengan wasit.

Moderasi di dalam Islam dikenal dengan istilah wasathiyyah. Menurut Salabi, wasathiyyah berasal dari bahasa Arab yang diambil dari akar katanya yaitu wasath yang

\footnotetext{
${ }^{8}$ Mattew Milles, Qualitative Data Analysis: A Methods Sourcebook, Third (USA: SAGE, 2014).

9 John W Creswell, Research Design: Pendekatan Metode Kualitatif, Kuantitatif, Dan Campuran, Empat (Yogyakarta: Pustaka Pelajar, 2019).

${ }^{10}$ Kemendikbud, Kamus Besar Bahasa Indonesia, V (Beta (21) Online, 2016). 


\section{Jurnal TAUJIH Jurnal Pendidikan Islam}

Vol. 14 No. 01 Januari-Juni 2021

P-ISSN : 2085-7934

\section{Program Studi \\ Pendidikan Agama Islam}

IAI Al-Qur'an Al-Ittifaqiah Indralaya

E-ISSN : 2774-7379

bermakna di tengah atau di antara ${ }^{11}$. Kata wasath juga memiliki banyak arti diantaranya adalah terbaik, adil, keseimbangan, utama, ke-sedangan-an, kekuatan, keamanan, persatuan, dan istiqamah. Sedangkan lawan dari moderasi (wasathiyyah) adalah berlebihan (tatharruf) dan melampaui batas (ghuluw) yang juga bermakna ekstrem dan radikal . ${ }^{12}$. Berdasarkan pada beberapa makna wasathiyyah sebagaimana di atas, dapat disimpulkan bahwa hakikatnya wasathiyyah memiliki sifat fleksibelitas dan kontekstualis tergantung dimana kata tersebut digunakan. Maka pada pada prinsipnya, Wasathiyyah adalah sikap dan perilaku yang tidak kaku namun juga tidak terlalu lentur, tidak bersifat memihak tapi punya prinsip serta mengandung nilai-nilai kebaikan.

Maka dalam konteks kehidupan beragama, moderasi beragama dapat didefinisikan sebagai pandangan, sikap dan perilaku beragama yang memegang prinsip keseimbangan dan keadilan serta mencari posisi di tengah yaitu antara eksterm kanan (radikal) dan ekstrem kiri (liberal) ${ }^{13}$. Moderasi beragama adalah konsep perilaku dalam kehidupan beragama untuk tidak bersikap fanatik, selalu toleran dan inklusif, menjunjung tinggi nilai keseimbangan, keadilan dan egaliter ${ }^{14}$. Moderasi beragama adalah cara beragama yang santun dan toleran, tidak radikal yaitu konservatif tekstualis serta mengabaikan konteks dan tidak pula liberal yaitu terlalu mendewakan akal dan mengabaikan teks ${ }^{15}$. Secara umum dapat disimpulkan bahwa moderasi beragama adalah cara pandang, sikap dan perilaku beragama yang menjauhi ekstreminitas, menjaga keseimbangan dan keadilan serta memilih jalan tengah.

11 Sauqi Futaqi, "Konstruksi Moderasi Islam (Wasathiyyah) Dalam Kurikulum Pendidikan Islam," PROCEEDINGS: Annual Conference for Muslim Scholars, 2018.

12 Mohammad Hashim Kamali, The Middle Path of Moderation in Islam: The Qur'anic Principles of Wasathiyyah (NEW YORK: Oxford University Press, 2015); Yusuf al Qardhawi, Fiqhu Al Wasathiyyah Al Islamiyyah Wa At-Tajdid (Ma;Alim Wa Manarat) (Mesir: Markaz al Qordhowi lil Wasathiyyah al Islamiyyah wa at-Tajdid, 2009); Shihab, Wasathiyyah: Wawasan Islam Tentang Moderasi Beragama.

${ }^{13}$ Kamali, The Middle Path of Moderation in Islam: The Qur'anic Principles of Wasathiyyah; Yusuf al Qardhawi, Al Khsosois Al 'Ammah Lil Islam (Kairo: Maktabah Wahbah, 1977); Shihab, Wasathiyyah: Wawasan Islam Tentang Moderasi Beragama; Kementerian Agama Republik Indonesia, Moderasi Beragama, Pertama. (Jakarta: Badan Litbang dan Diklat Kementerian Agama Republik Indonesia, 2019).

14 Mohamad Fahri, "Moderasi Beragama Di Indonesia"; Kementerian Agama Republik Indonesia, Moderasi Beragama; Haslina Ibrahim, "The Principle of Wasatiyyah (Moderation) and the Social Concept of Islam: Countering Extremism in Religion," AL-ITQĀN, no. 1 November (2018): 39-48.

15 Ahmad Najib Burhani, "Pluralism, Liberalism and Islamism: Religious Outlook of Muhammadiyah," Studia Islamika 25, no. 3 (2018), https://doi.org/10.15408/sdi.v25i3.7765; Syamsul Arifin, "Islamic Religious Education and Radicalism in Indonesia : Strategy of de-Radicalization through Strengthening the Living Values," Indonesian Journal of Islam and Muslim Societies 6, no. 1 (2016): 93-126, https://doi.org/10.18326/ijims.v6i1.93126. 


\section{Jurnal TAUJIH Jurnal Pendidikan Islam}

Vol. 14 No. 01 Januari-Juni 2021

P-ISSN : 2085-7934

\section{Program Studi Pendidikan Agama Islam \\ IAI Al-Qur'an Al-Ittifaqiah Indralaya \\ E-ISSN : 2774-7379}

Moderasi beragama memiliki dua prinsip dasar yang menjadi landasan di dalam bersikap dan berperilaku keagamaan. Pertama, keadilan yaitu sikap dan perilaku untuk tidak memihak atau berat sebelah, selalu berpihak pada kebenaran, menempatkan sesuatu pada tempatnya serta memberikan sesuatu sesuai porsinya, dalam arti, moderasi beragama adalah sikap untuk selalu menjunjung tinggi keadilan dan kebenaran di dalam kehidupan beragama; Kedua, keseimbangan yaitu sikap untuk selalu komitmen menyeimbangkan antara akal dan wahyu, antara dunia dan akhirat, antara teks dan konteks, antara jasmani dan rohani dan sebagainya. keseimbangan bukan bermakna tidak berprinsip tapi justru bermakna tegas untuk memiliki pendirian dan tidak condong kea rah salah satu sisi ${ }^{16}$. Moderasi beragama sebagai konsep beragama yang menjunjung tinggi nilai keseimbangan menurut Shihab harus mampu menyeimbangkan antara teks dan ide, antara ruh dan jasad, antara duniawi dan ukhrawi, antara agama dan negara, antara ilmu dan agama, antara yang lama dan yang baru, dan antara modernitas dan tradisi ${ }^{17}$. Apabila kedua prinsip dasar moderasi beragama tersebut mampu dijalankan dengan baik di dalam sikap dan perilaku beragama di dalam kehidupan sehari-hari maka toleransi dan kerukunan kehidupan beragama baik internumat atau antarumat beragama akan dapat terwujud dengan baik.

Untuk dapat memahami moderasi beragama secara baik dan benar, maka setiap orang harus mengetahui indikator-indikator dari moderasi beragama itu sendiri. Terdapat beberapa indikator moderasi beragama yang dapat dijadikan acuan dalam bersikap dan berperilaku keagamaan khususnya di negara Indonesia yang berkarakteristik kepulauan dan multikultural. Indikator moderasi beragama tersebut adalah: 1) menjunjung tinggi komitmen kebangsaan; 2) bersifat toleran dan harmonis; 3) ideologi anti kekerasan; 4) mengakomodir kebudayaan lokal; 5) dapat diterima oleh akala tau bersifat rasionalis 6) kontekstualis dan cenderung tekstualis; 7) terdapat ijtihad di dalam pengambilan hukum yang tidak terdapat di dalam sumber utama ${ }^{18}$. Moderasi beragama tidak memandang agama hanya sebatas tuntunan bagaimana seorang hamba beribadah kepada Tuhannya, namun lebih dari itu adalah sebagai tuntunan bagaimana manusia dapat bermuamalah

\footnotetext{
${ }^{16}$ Kementerian Agama Republik Indonesia, Moderasi Beragama.

${ }^{17}$ Shihab, Wasathiyyah: Wawasan Islam Tentang Moderasi Beragama.

${ }^{18}$ Futaqi, "Konstruksi Moderasi Islam (Wasathiyyah) Dalam Kurikulum Pendidikan Islam"; Kementerian Agama Republik Indonesia. Moderasi Beragama. Umar Al Faruq dan Dwi Noviani: Pendidikan Moderasi Beragama Sebagai Perisai Radikalisme di Lembaga Pendidikan.
} 


\section{Jurnal TAUJIH Jurnal Pendidikan Islam}

Vol. 14 No. 01 Januari-Juni 2021

P-ISSN : 2085-7934

\section{Program Studi \\ Pendidikan Agama Islam}

IAI Al-Qur'an Al-Ittifaqiah Indralaya

E-ISSN : 2774-7379

dengan baik antarsesama manusia dan alam semesta sebagai ciptaan Allah. Moderasi beragama bertujuan tercapainya kebahagiaan baik di dunia dan di akhirat.

Terdapat beberapa nilai luhur yang terkandung di dalam konsep moderasi beragama yang selanjutnya menjadi karakteristik moderasi beragama yaitu: 1) keseimbangan (tawazun) yaitu menyeimbangkan antara akal dan wahyu, antara duniawi dan ukrawi, antara teks dan konteks, antara jasmani dan rohani, dan seterusnya; 2) moderat (tawassuth) yaitu berada di tengah atau diantara dua ekstreminitas; 3) keadilan (i'tidal) yaitu menjunjung prinsip keadilan dengan tidak berat sebelah dengan memberikan sesuatu sesuai dengan hak dan porsinya; 4) toleran (tasamuh) yaitu menghargai segala bentuk perbedaan dengan tidak mengklaim kebenaran atau kesalahan orang atau kelompok lainnya; 5) egaliter (musawah) yaitu tidak pilih kasih (diskriminatif) dengan memandang persamaan hak; 6) musyawarah (tasyawur) yaitu bermusyawah untuk mencapai kesepakatan mengenai persoalan dan kepentingan bersama; 7) reformasi (ishlah) yaitu reformasi atau melakukan perbaikan ke depan untuk menjadi lebih baik; 8) perioritas (aulawiyyah) yaitu menetapkan sesuatu yang memiliki urgensitas tinggi untuk menjadi perioritas utama;9) berkembang dan inovatif (tathawwur wa ibtikar) yaitu memiliki kemampuan untuk melakukan pengembangan dan menciptakan ide kreatif inovatif untuk kemajuan; 10) berkeadaban (tahaddur) yaitu tetap berupaya untuk menjunjung tinggi nilai-nilai peradaban yang ada ${ }^{19}$.

Moderasi beragama menjadi harapan semua pihak sebagai solusi mengatasi konflik keagamaan dan konsep untuk dapat mewujudkan kehidupan beragama di dalam bingkai keharmonisan dan toleransi. Namun, untuk mampu mewujudkan harapan yang dinginkan tersebut tidaklah mudah. Oleh karenanya, dibutuhkan beberapa langkah sebagai berikut: 1) memahami dengan baik dan benar ajaran agama yang bersumber dari al-Qur'an dan asSunnah terutama pemahaman secara mendalam akan substansi ajaran agama yang ada; 2) mampu mendialogkan antara ilmu dan iman atau anatar akal dan wahyu sehingga mampu meyelaraskan di antara keduanya; 3) menjunjung tinggi nilai-nilai keadilan, sosial kemanusian dan kebebasan; 4) kolaborasi dengan para ahli di dalam melakukan tajdid atau

19 Umar Al Faruq and Dwi Noviani, "Urgensi Internalisasi Nilai-Nilai Islam Nusantara Dalam Pembentukan Karakter Moderat," in Konferensi Nasional Pendidikan Islam (Malang: Fakultas Agama Islam Universitas Islam Malang, 2020), 149-56; Afrizal Nur and Lubis Mukhlis, "Konsep Wasathiyah Dalam Al-Quran (Studi Komparatif Antara Tafsir Al-Tahrîr Wa at-Tanwîr Dan Aisar at-Tafâsîr)," An-Nur 4, no. 2 (2015): 205-25. Umar Al Faruq dan Dwi Noviani: Pendidikan Moderasi Beragama Sebagai Perisai 


\section{Jurnal TAUJIH \\ Jurnal Pendidikan Islam}

Vol. 14 No. 01 Januari-Juni 2021

P-ISSN : 2085-7934

\section{Program Studi Pendidikan Agama Islam \\ IAI Al-Qur'an Al-Ittifaqiah Indralaya \\ E-ISSN : 2774-7379}

pembaharuan dengan tetap bersandar pada ajaran agama; 5) membangun toleransi di tengah perbedaan dengan cara menjalin hubungan baik dengan semua pihak dan kalangan; 6) meneguhkan persatuan dan kesatuan di tengah perbedaan; 7) tetap melestarikan dan merawat dengan baik peninggalan khazanah pemikiran para tokoh terdahulu ${ }^{20}$.

Selanjutnya menurut Shihab, agar seseorang dapat menerapkan wasathiyyah di dalam kehidupannya setidaknya ia memerlukan 3 hal dari dirinya yaitu: pertama, memiliki pengetahuan yang benar dan luas tentang ajaran agama beserta segala perbedaan yang ada di dalamnya; kedua, memiliki kemampuan untuk mengendalikan dan menyeimbangkan emosinya sehingga terhindar dari sikap dan perilaku berlebihan; ketiga, memiliki kewaspadaan dan sikap kehati-hatian di dalam setiap pengambilan keputusan ${ }^{21}$.

\section{B. Implementasi Pendidikan Moderasi Beragama di SMA Selamat Pagi Indonesia Batu}

SMA Selamat Pagi Indonesia Batu adalah salah satu lembaga pendidikan formal di Indonesia yang sudah lama menerapkan konsep moderasi beragama di dalam pembentukan karakter moderat peserta didik. Lembaga pendidikan yang berkonsep sekolah multikultural tersebut sejak awal telah berkomitmen untuk menjadi lembaga pendidikan yang dapat mengakomodir segala bentuk perbedaan baik agama, suku, ras, bahasa dan budaya. Bagi lembaga tersebut, perbedaan latar belakang peserta didik baik agama, etnis, bahasa, dan budaya tidak boleh menjadikan mereka untuk bersikap dan berperilaku intoleran dan radikal, tapi justru sebaliknya, adanya perbedaan tersebut harus mampu dipahami dengan baik oleh mereka untuk dapat belajar berinteraksi dan beradaptasi dengan segala perbedaan yang ada.

Pada awal mengunjungi lokasi penelitian, peneliti menemukan atmosfer yang sangat menarik terkait kehidupan beragama di tempat tersebut, di mana peneliti menjumpai bangunan tempat ibadah mulai dari mushola. Gereja, vihara, dan pura yang sengaja dibangun secara bberdekatan di tempat tersebut. Tempat ibadah tersebut sengaja dibangun atau didirikan untuk digunakan sebagai tempat beribadah bagi seluruh peserta didik sesuai dengan agama dan keyakinan mereka masing-masing. Meskipun bangunan-bangunan tersebut masih cenderung bersifat mini, namun tempat ibadah yang dibangun tersebut sudah dapat merepresentasikan moderasi beragama telah berjalan di tempat tersebut. Di

${ }^{20}$ Shihab, Wasathiyyah: Wawasan Islam Tentang Moderasi Beragama.

${ }^{21}$ Shihab. 


\section{Jurnal TAUJIH Jurnal Pendidikan Islam}

Vol. 14 No. 01 Januari-Juni 2021

P-ISSN : 2085-7934
Program Studi

Pendidikan Agama Islam

IAI Al-Qur'an Al-Ittifaqiah Indralaya

E-ISSN : 2774-7379

tempat ini, nilai-nilai agama seperti toleransi dan kasih sayang ditanamkan ke dalam diri peserta didik melalui penyadaran akan keberagaman agar mereka mampu menerima perbedaan serta dapat bersikap dan berperilaku toleran dan moderat.

Setiap siswa yang menempuh pendidikan si SMA SPI Batu sejak awal sudah ditanamkan di dalam diri mereka nilai-nilai untuk berkomitmen menerima segala macam perbedaan yang ada. Menurut salah satu guru agama Islam yang berhasil ditemui oleh peneliti menjelaskan bahwa para siswa sejak awal diajari untuk menerima segala perbedaan yang ada di sekitar mereka. Setiap peserta didik diminta untuk saling menghormati antara pemeluk agama yang satu dengan yang lain. Untuk dapat bersikap dan berperilaku moderat, para siswa tidak hanya belajar moderasi beragama melalui pembelajaran di kelas akan tetapi mereka juga belajar di asrama tempat mereka tinggal dan juga dari lingkungan sekolah dan sekitarnya di mana mereka menjalani kehidupan seharihari. Hal senada disampaikan oleh salah satu siswa yang menjelaskan bahwa para peserta didik sejak awal masuk ke SMA SPI Batu sudah mendapat pendampingan dari kakak kelas atau pengurus asrama yang secara intensif membimbing mereka untuk dapat belajar memahami dan menerima segala perbedaan yang ada. Selain itu, para guru juga turut memantau perkembangan perilaku mereka sehari-hari.

Lebih lanjut, implementasi pendidikan moderasi beragama di sekolah yang mendapat julukan the miniature of Indonesia dilakukan secara integratif dengan cara mengintegrasikan sistem pendidikan yang ada di dalam kelas atau sekolah, asrama, dan Kampung Kids (KD). Pendidikan moderasi beragam di kelas dilakukan melalui pembelajaran materi yang menjadi muatan materi keagamaan, sedangkan di asrama dan Kampung Kids (KD) para peserta didik belajar dari pengalaman langsung kehidupan mereka melalui berbagai kegiatan keagamaan dan kegiatan sosial yang ada. Jadi, para peserta didik tidak hanya memperoleh pendidikan moderasi beragama melalui materi keagamaan yang disampaikan oleh guru agama mereka di dalam kelas akan tetapi mereka juga dapat memperoleh pelajaran tersebut di luar kelas seperti di asrama dan Kampung Kids yang dikemas ke dalam berbagai kegiatan.

Integrasi pembelajaran moderasi beragama yang dilakukan oleh SMA SPI Batu tersebut sangat berdampak positif terhadap hasil pembentukan karakter moderat peserta didik, karena mereka selain mendapatkan pendidikan secara teoritis di kelas mereka dapat belajar langsung dari pengalaman hidup mereka selama di asrama yang merupakan tempat 


\section{Jurnal TAUJIH Jurnal Pendidikan Islam}

Vol. 14 No. 01 Januari-Juni 2021

P-ISSN : 2085-7934
Program Studi

Pendidikan Agama Islam

IAI Al-Qur'an Al-Ittifaqiah Indralaya

E-ISSN : 2774-7379

tinggal mereka. Lingungan sekolah dan asrama sangat berpengaruh terhadap proses pembentukan karakter mereka. Selain itu, keterlibatan para siswa di dalam berbagai kegiatan baik kegiatan keagamaan maupun kegiatan sosial telah memberikan pengalaman pagi mereka sehingga mereka akhirnya dapat menjadi terbiasa untuk berinteraksi dengan teman-temannya yang memiliki varian perbedaan. Pengalaman dan pembiasaan yang dilakukann oleh para siswa adalah faktor penting yang sangat berpengaruh terhadap proses pembentukan karakter mereka. Hal ini sebagaimana pandangan Komalasari dan Sodiq bahwa karakter seseorang dibentuk oleh pengalaman dan kebiasaan yang ia alami ${ }^{22}$.

Praktik pendididkan moderasi beragama di kelas dilakukan melalui pembelajaran pendidikan agama dengan menggunakan metode Contextual Teaching Learning (CTL) yaitu metode pembelajaran agama yang mengedepankan aspek kontekstual daripada teks, sehingga ajaran agama tidak diajarkan sebagai doktrin atau bersifat dogmatis tekstualis melainkan lebih memperhatikan aspek konteks. Nilai-nilai agama seperti toleransi dan kasih sayang ditanamkan ke dalam diri peserta didik sejak dini sehingga mereka dapat memaknai arti setiap perbedaan yang ada. Adapun pembelajaran moderasi beragama di asrama dilakukan langsung melalui kegiatan keagamaan dan pendampingan seperti diskusi kelompok dan sebagainya dalam bentuk sharing bersama yang melibatkan beberapa peserta didik dengan latar belakang agama yang berbeda. Para peserta didik juga diminta untuk saling membantu setiap kegiatan keagamaan seperti peringatan hari besar dan lain sebagainya yang dilakukan setiap pemeluk agama.

Sementara untuk memupuk jiwa kebersamaan, saling menghormati dan persatuan, para peserta didik dilibatkan di dalam berbagai kegiatan sosial bersama di Kampung Kids (KD). Para siswa dibagi menjadi beberapa kelompok dan devisi untuk dapat berkontribusi di dalam setiap kegiatan yang ada di dalam devisinya masign-masing. Di dalam setiap devisi diisi oleh beberapa peserta didik dengan latar belakang agama yang berbeda dengan tujuan agar mereka dalapat saling mengenal dan berinteraksi antara yang satu dengan yang lainnya. Selain itu, di dalam setiap devisi juga terdapat seorang pemeimpin yang ditunjuk berdasarkan kualitas atau kompetensinya dan bukan berdasarkan pada agamanya. Hal tersebut sebagaimana yang disampaikan oleh salah satu peserta didik bahwa pemimpin

${ }^{22}$ Kokom Komalasari and Kokom Saipudin, Pendidikan Karakter (Konsep Dan Aplikasi Living Value Education), Pertama (Bandung: PT Refika Aditama, 2017); Ahmad Sodiq, Prophetic Character Building, 1st ed. (Jakarta: Kencana, 2018). 


\section{Jurnal TAUJIH Jurnal Pendidikan Islam}

Vol. 14 No. 01 Januari-Juni 2021

P-ISSN : 2085-7934
Program Studi

Pendidikan Agama Islam

IAI Al-Qur'an Al-Ittifaqiah Indralaya

E-ISSN : 2774-7379

devisi dipilih berdasarkan kemampuan dan bukan karena mayoritas agama yang dianut. Selain itu juga, pembentukan perilaku peserta didik secara langsung dipengaruhi oleh aktifitas pengalaman mereka sehari-hari selama berada di lingkungan sekitar mereka.

Secara umum, proses pendidikan moderasi beragama di SMA SPI Batu yang dilakukan dengan sistem integratif dapat dilihat pada diagram berikut.

Diagram 1. Proses Pendidikan Moderasi Beragama di SMA SPI Batu

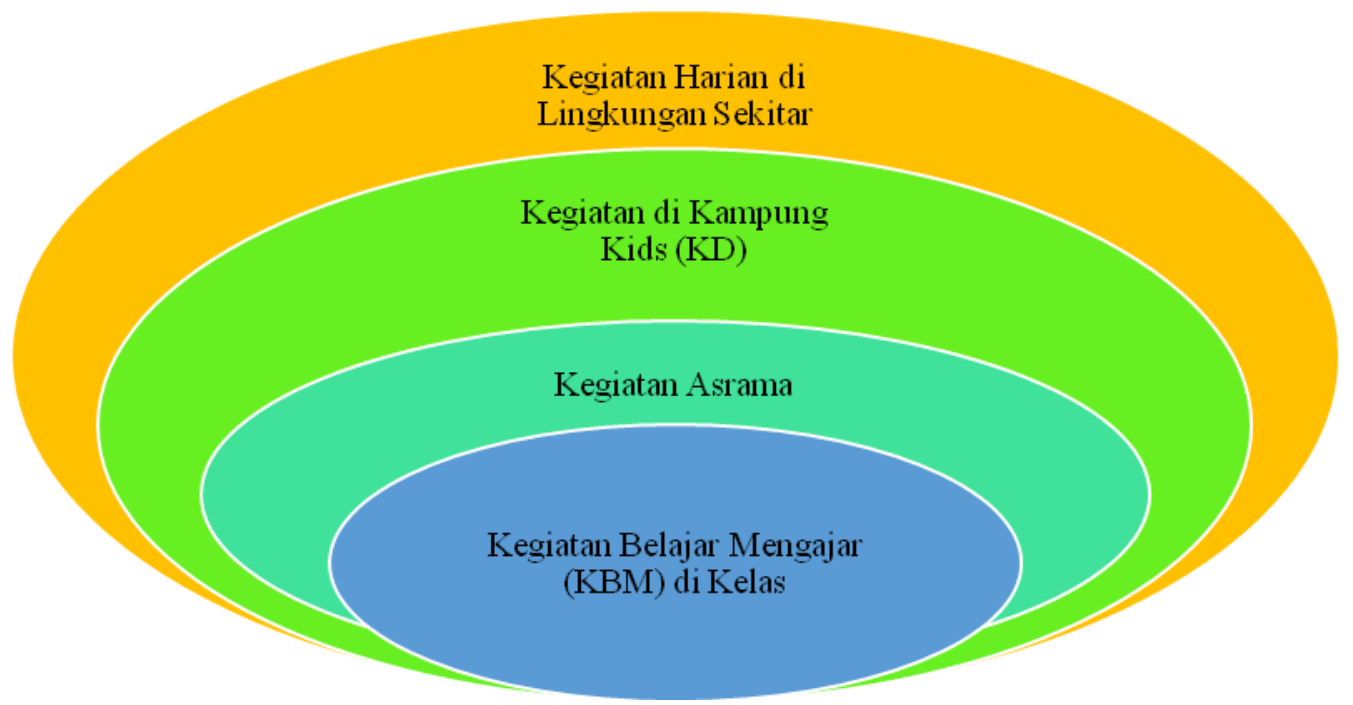

Berangkat dari diagram di atas dapat dipahami bahwa pendidikan moderasi beragama di SMA SPI Batu dilakukan secara integratif melalui kegiatan-kegiatan yang diselenggarakan di empat tempat yang berbeda yang saling terkait antara satu dan lainnya yaitu Kegiatan Belajar Mengajar (KBM) di dalam kelas, kegiatan di asrama, kegiatan di Kampung Kids (KD), dan kegiatan harian di lingkungan sekitar. Secara umum, proses pendidikan moderasi beragama di SMA SPI Batu dapat dikategorikan menjadi dua yaitu teoretis dan praktis. Dalam tataran teoretis, para peserta didik memperoleh materi pendidikan moderasi beragama melalui pembelajaran materi keagaaan di dalam kelas yang disampaikan oleh masing-masing guru agama, sedangkan secara praktis, mereka memperolehnya lanngsung dari kegiatan-kegiatan yang ada di asrama, kampung Kids (KD), dan lingkungan di sekitar mereka. Menurut keterangan salah satu siswi yang mejadi informan di dalam penelitian ini bahwa ia merasa senang sekali dengan sistem pembelajaran di SMA SPI Batu karena pendidikan tidak hanya diberikan secara teoretis tapi juga langsung dipraktekkan di lapangan, bahkan pendidikan secara praktis lebih dominan daripada teori. 


\section{Jurnal TAUJIH Jurnal Pendidikan Islam}

Vol. 14 No. 01 Januari-Juni 2021

P-ISSN : 2085-7934
Program Studi

Pendidikan Agama Islam

IAI Al-Qur'an Al-Ittifaqiah Indralaya

E-ISSN : 2774-7379

Selain penekanan terhadap nilai toleransi dan egaliter, pendidikan moderasi beragama di SMA SPI Batu juga berupaya untuk menanamkan nilai keseimbangan kepada peserta didik agar mereka mampu bersikap dan berperilaku moderat dan seimbang, yaitu menyeimbangkan antara duniawi dan ukhrawi, antara agama dan sosial, antara urusan pribadi dan urusan bersama. Oleh karenanya, di dalam beberapa kegiatan sosial, para siswa diminta untuk tidak membawa nama agama ke dalam kegiatan sosial bersama yang diikuti oleh peserta didik yang berbeda keyakinan. Para peserta didik diminta untuk tidak mencampuradukkan antara agama dan kegiatan sosial bersama agar tidak menimbulkan kegaduhan di antara mereka. Meskipun begitu, para peserta didik tetap diminta untuk saling toleran terhadap teman mereka yang ingin melaksanakan ibadah pada saat kegiatan berlangsung. Jika terdapat peserta didik yang beragama Islam ingin melakukan ibadah, maka peserta didik non-Muslim yang lain harus bersikap toleran dan begitu pula sebaliknya. Pembelajaran dan penananamn nilai keseimbangan kepada peserta didik dapat berjalan dengan mudah karena sejak awal para peserta didik sudaha diberi pemahaman akan pentingnya menghargai perbedaan di antara mereka.

Sementara jika dilihat dari sisi kuantitas, mayoritas peserta didik SMA SPI Batu adalah beragama Islam dengan jumlah 94 orang. Sementara peserta didik yang lain yang beragama Kristen sebanyak 64 orang, Katholik 62 orang, Hindu 9 orang, Budha 17 orang, dan Konghuchu 1 orang. Sedangkan data pendidik, mayoritas mereka juga adalah Muslim yaitu 13 orang. Sementara pendidik yang lain yang beragama Kristen sebanyak 1 orang, Katholik 2 orang, Budha 1 orang, dan Hindu 1 orang. Namun meskipun begitu, para guru atau sekolah tidak pernah pilih kasih atau diskriminasi terhadap para peserta didik di dalam proses pendidikan dan pembelajaran baik di dalam kelas maupun di luar kelas. Para peserta didik diberikan hak dan perlakuan yang sama di dalam beribadah sesuai dengan agama mereka. Sistem sekolah berusaha untuk memperlakukan semua peserta didik dengan adil tanpa melihat latar belakang agama mereka. Peserta didik memperoleh porsi kesempatan dan waktu sebagaimana porsi yang mereka miliki di dalam pelaksanaan ibadah. Nilai-nilai moderasi beragama seperti toleransi, keseimbangan, dan keadilan sengaja ditanamkan ke dalam diri peserta didik agar mereka mampu bersikap dan berperilaku moderat serta terhindar dari sikap radikalisme dan fanatisme.

Untuk memupuk jiwa solidaritas dan kepedulian sosial keagamaan, peserta didik diminta untuk saling tolong menolong antarsesama tanpa melihat latar belakang agama. 


\section{Jurnal TAUJIH \\ Jurnal Pendidikan Islam}

Vol. 14 No. 01 Januari-Juni 2021

P-ISSN : 2085-7934
Program Studi

Pendidikan Agama Islam

IAI Al-Qur'an Al-Ittifaqiah Indralaya

E-ISSN : 2774-7379

Sebagai contoh, peserta non-Muslim bisa membantu peserta didik yang beragama Islam saat mereka melakukan persiapan untuk merayakan hari raya mereka, dan begitu pula sebaliknya, peserta didik Muslim bisa membantu mereka yang non-Muslim saat mereka mempersiapkan acara perayaan hari besarnya. Sikap dan perilaku tolong menolong tersebut juga dilakukan di dalam beberapa kegiatan keagamaan yang lain. Jiwa kepedulian antarsesama di antara para peserta didik dapat terlihat pada saat mereka dapat saling mengingatkan untuk menajalankan ibadah meskipun mereka berbeda agama. Hal ini sebagaimana paparan guru agama dan peserta didik di sana bahwa para peserta didik sudah terbiasa untuk saling mengingatkan antasesama teman dalam menjalankan ibadah. Jika tiba waktu sholat dan terdapat peserta didik Muslim yang belum sholat, maka peserta didik non-Muslim mengingatkannya untuk segera melakukan sholat, dan begitu pula sebaliknya saat kebaktian di hari Minggu, peserta didik Muslim juga mengingatkan teman yang Kristen untuk melakukan ibadah,dan begitu pula seterusnya.

Dari beberapa uraian diatas, setidaknya ada beberapa nilai yang terkandung di dalam moderasi beragama yang dapat diajarkan dan diterapkan di SMA SPI Batu. Nilai-nilai tersebut sebagaimana tabel berikut:

Tabel 1. Nilai-Nilai Moderasi Beragama di SMA SPI Batu

\begin{tabular}{|c|l|l|}
\hline Nilai & \multicolumn{1}{|c|}{ Deskripsi } & \multicolumn{1}{|c|}{ Indikator } \\
\hline $\begin{array}{c}\text { Toleransi } \\
\text { (tasamuh) }\end{array}$ & $\begin{array}{l}\text { Sikap dan perilaku menerima } \\
\text { segala bentuk perbedaan }\end{array}$ & $\begin{array}{l}\text { Setiap siswa mampu untuk } \\
\text { saling menghormati } \\
\text { antarteman yang bebeda } \\
\text { keyakinan saat melakukan } \\
\text { ibadah }\end{array}$ \\
\hline $\begin{array}{c}\text { Egaliter } \\
\text { (musawah) }\end{array}$ & $\begin{array}{l}\text { Tidak diskriminatif dan } \\
\text { kewajiban persamaan hak dan }\end{array}$ & $\begin{array}{l}\text { Setiap siswa mendapat } \\
\text { perlakukan dan hak yang sama } \\
\text { di dalam menjalankan aktifitas } \\
\text { keagamaan }\end{array}$ \\
\hline $\begin{array}{l}\text { Keadilan } \\
\text { ('adalah })\end{array}$ & $\begin{array}{l}\text { Menempatkan sesuatu pada } \\
\text { tempatanya dan memberikan } \\
\text { porsi sesuai dengan porsinya }\end{array}$ & $\begin{array}{l}\text { Setiap siswa memperoleh } \\
\text { porsi sesuai dengan hak yang } \\
\text { dimilikinya }\end{array}$ \\
\hline
\end{tabular}




\section{Jurnal TAUJIH \\ Jurnal Pendidikan Islam}

Vol. 14 No. 01 Januari-Juni 2021

P-ISSN : 2085-7934
Program Studi

Pendidikan Agama Islam

IAI Al-Qur'an Al-Ittifaqiah Indralaya

E-ISSN : 2774-7379

\begin{tabular}{|c|l|l|}
\hline $\begin{array}{c}\text { Keseimbangan } \\
\text { (tawazun })\end{array}$ & Tidak berat sebelah & $\begin{array}{l}\text { Setiap siswa mampu } \\
\text { menyeimbangkan antara } \\
\text { waktu belajar, ibadah, bekerja, } \\
\text { dan bermain }\end{array}$ \\
\hline $\begin{array}{c}\text { Moderat } \\
\text { tawassuth })\end{array}$ & $\begin{array}{l}\text { Memposisikan untuk berada } \\
\text { di tengah dan tidak } \\
\text { berlebihan }\end{array}$ & $\begin{array}{l}\text { Siswa tidak berperilaku } \\
\text { fanatik serta tidak berlebihan } \\
\text { di dalam beribadah }\end{array}$ \\
\hline
\end{tabular}

\section{Kesimpulan}

Pendidikan moderasi beragama adalah hal penting yang perlu mendapat perhatian khusus dari para pemerhati pendidikan khususnya bagi lembaga yang memiliki siswa dengan heteregonitas latar belakang. Dari paparan di atas dapat disimpulkan bahwa proses pendidikan moderasi beragama di SMA Selamat Pagi Indonesia Batu telah dilakukan sejak awal sekolah tersebut berdiri dan dilakukan dengan baik. Secara komitmen, SMA SPI Batu melakukan pembelajaran moderasi beragama melalui sistem integratif yaitu melalui proses KBM di kelas, kegiatan asrama, kegiatan di Kampung Kids (KD), dan kegiatan harian di lingkungan sekitar. Setidaknya terdapat lima nilai moderasi beragama yang dipelajari oleh peserta didik dan ditanamkan ke dalam diri mereka yaitu nilai toleransi, keseimbangan, egaliter, keadilan, dan moderasi. Selain itu, para peserta didik juga belajar nilai-nilai kehidupan yang juga merupakan cerminan dari ajaran agama yaitu kasih sayang, persaudaraan, kedamaian, kepedulian, dan persatuan. Keberhasilan proses pendidikan moderasi beragama di SMA SPI Batu dalam membentuk perilaku moderat dan toleran para peserta didik adalah juga kebersilan dalam mencegah dan memberantas radikalisme yang ada di lembaga pendidikan. Oleh karenanya, implementasi pendidikan moderasi beragama dapat menjadi rekomendasi bagi lembaga pendidikan lainnya dalam rangka mencegah timbulnya perilaku radikal di lingkungan sekolah atau lembaga pendidikan. 


\section{Jurnal TAUJIH Jurnal Pendidikan Islam}

Vol. 14 No. 01 Januari-Juni 2021

P-ISSN : 2085-7934
Program Studi

Pendidikan Agama Islam

IAI Al-Qur'an Al-Ittifaqiah Indralaya

E-ISSN : 2774-7379

\section{DAFTAR PUSTAKA}

Aminah, Sitti. "Peran Pemerintah Menanggulangi Radikalisme Dan Terorisme Di Indonesia." JURNAL KELITBANGAN 04, no. 01 (2016): 41.

Anonimus. "Undang-Undang Sistem Pendidikan Nasional." Acta Padiatrica, 2003. https://doi.org/10.1111/j.1651-2227.1982.tb08455.x.

Arifin, Syamsul. "Islamic Religious Education and Radicalism in Indonesia: Strategy of deRadicalization through Strengthening the Living Values." Indonesian Journal of Islam and Muslim Societies 6, no. 1 (2016): 93-126. https://doi.org/10.18326/ijims.v6i1.93-126.

Asror Baisuki, Ta'rif. "Penanaman Karakter Moderat Di Ma'had 'Aly Situbondo." Edukasi: Jurnal Penelitian Pendidikan Agama Dan Keagamaan 15, no. 3 (2017): 459-70.

Burhani, Ahmad Najib. "Pluralism, Liberalism and Islamism: Religious Outlook of Muhammadiyah." Studia Islamika 25, no. 3 (2018). https://doi.org/10.15408/sdi.v25i3.7765.

Creswell, John W. Research Design: Pendekatan Metode Kualitatif, Kuantitatif, Dan Campuran. Empat. Yogyakarta: Pustaka Pelajar, 2019.

Faridi. Model Pendidikan Karakter Berbasis Nilai-Nilai Rabbani. Pertama. Malang: Baskara Media Aditya Media Group, 2020.

Faruq, Umar Al. "Peluang Dan Tantangan Pendidikan Muhammadiyah Di Era 4.0." Ar-Risalah: Media Keislaman, Pendidikan Dan Hukum Islam XVIII, no. 1 (2020): 13-30.

_. "Politik Dan Kebijakan Tentang Majelis Taklim Di Indonesia ( Analisis Kebijakan Peraturan Menteri Agama No . 29 Tahun 2019 ).” AL MURABBI: Jurnal Pendidikan Agama Islam 1, no. 1 (2020): 41-59.

Faruq, Umar Al, and Dwi Noviani. "Urgensi Internalisasi Nilai-Nilai Islam Nusantara Dalam Pembentukan Karakter Moderat." In Konferensi Nasional Pendidikan Islam, 149-56. Malang: Fakultas Agama Islam - Universitas Islam Malang, 2020.

Futaqi, Sauqi. "Konstruksi Moderasi Islam (Wasathiyyah) Dalam Kurikulum Pendidikan Islam." PROCEEDINGS: Annual Conference for Muslim Scholars, 2018.

Hanapi, Mohd Shukri. "The Wasatiyyah (Moderation) Concept in Islamic Epistemology: A Case Study of Its Implementation in Malaysia." International Journal of Humanities and Social Science 4, no. 9(1) (2014): 51-62.

Hermawan, M. A. "Nilai Moderasi Islam Dan Internalisasinya Di Sekolah." Insania: Jurnal Pemikiran Alternatif Kependidikan 25, no. 1 (2020): 31-43.

Hiqmatunnisa, Hani, and Ashif Az Zafi. "Penerapan Nilai-Nilai Moderasi Islam Dalam Pembelajaran Fiqih Di Ptkin Menggunakan Konsep Problem-Based Learning." JIPIS 29, no. 1 (2020): 27-35.

Ibrahim, Haslina. "The Principle of Wasatiyyah (Moderation) and the Social Concept of Islam: Countering Extremism in Religion." $A L-I T Q \bar{A} N$, no. 1 November (2018): 39-48.

Umar Al Faruq dan Dwi Noviani: Pendidikan Moderasi Beragama Sebagai Perisai

Radikalisme di Lembaga Pendidikan. 


\section{Jurnal TAUJIH Jurnal Pendidikan Islam}

Vol. 14 No. 01 Januari-Juni 2021

P-ISSN : 2085-7934
Program Studi

Pendidikan Agama Islam

IAI Al-Qur'an Al-Ittifaqiah Indralaya

E-ISSN : 2774-7379

Idhom, Addi M, and Terry Muthahhari. "Survei $\{$ UIN $\}$ Jakarta: Intoleransi Tumbuh Di Banyak Sekolah Dan Kampus - \{Tirto.ID\}.” Tirto.Id. Tirto.id, 2017.

Insan, Khoirul Qolbi. "LHS Dan Moderasi Beragama.” Direktorat Jenderal Pendidikan Islam Kementerian Agama RI, 2019.

Kaawoan, Selviyanti. "Pendidikan Agama Islam Dalam Membentuk Perilaku Toleran Pada Warga Sekolah.” Manajement Pendidikan Islam, 2014.

Kamali, Mohammad Hashim. The Middle Path of Moderation in Islam: The Qur'anic Principles of Wasathiyyah. NEW YORK: Oxford University Press, 2015.

Kemendikbud. Kamus Besar Bahasa Indonesia. V. Beta (21) Online, 2016.

Kementerian Agama Republik Indonesia. Moderasi Beragama. Pertama. Jakarta: Badan Litbang dan Diklat Kementerian Agama Republik Indonesia, 2019.

Komalasari, Kokom, and Kokom Saipudin. Pendidikan Karakter (Konsep Dan Aplikasi Living Value Education). Pertama. Bandung: PT Refika Aditama, 2017.

MI, TimRed. "Survei Wahid Institute: Intoleransi-Radikalisme Cenderung Naik." 18 Januari, 2020. https://mediaindonesia.com/read/detail/284269-survei-wahid-institute-intoleransiradikalisme-cenderung-naik.

Milles, Mattew. Qualitative Data Analysis: A Methods Sourcebook. Third. USA: SAGE, 2014.

Mohamad Fahri, Ahmad Zainuri. "Moderasi Beragama Di Indonesia.” Jurnal.Radenfatah.Ac.Id 25, no. 2 (2019). http://jurnal.radenfatah.ac.id/index.php/intizar/article/view/5640.

Muchith, Muhammad Saekan. "Radikalisme Dalam Dunia Pendidikan.” Addin 10, no. 1 (2016): 163. https://doi.org/10.21043/addin.v10i1.1133.

Nur, Afrizal, and Lubis Mukhlis. "Konsep Wasathiyah Dalam Al-Quran (Studi Komparatif Antara Tafsir Al-Tahrîr Wa at-Tanwîr Dan Aisar at-Tafâsîr)." An-Nur 4, no. 2 (2015): 20525.

PPIM UIN Jakarta. “Survei PPIM_58 Persen Siswa Berpandangan Radikal,” 2020.

. "Survei PPIM 2018: Menyibak Intoleransi Dan Radikalisme Guru." Ppim.Uinjkt.Ac.Id, 2018. https://conveyindonesia.com/survei-ppim-2018-menyibak-intoleransi-danradikalisme-guru/.

Purwanto, Yedi, Qowaid Qowaid, Lisa'diyah Ma'rifataini, and Ridwan Fauzi. "Internalisasi Nilai Moderasi Melalui Pendidikan Agama Islam Di Perguruan Tinggi Umum." EDUKASI: Jurnal Penelitian Pendidikan Agama Dan Keagamaan, 2019. https://doi.org/10.32729/edukasi.v17i2.605.

Qard \}a>wi, Yusuf al. Al Khosois Al 'Ammah Lil Islam. Kairo: Maktabah Wahbah, 1977.

Fiqhu Al Wasathiyyah Al Islamiyyah Wa At-Tajdid (Ma;Alim Wa Manarat). Mesir: Markaz al Qordhowi lil Wasathiyyah al Islamiyyah wa at-Tajdid, 2009. 


\section{Jurnal TAUJIH \\ Jurnal Pendidikan Islam}

Vol. 14 No. 01 Januari-Juni 2021

P-ISSN : 2085-7934
Program Studi

Pendidikan Agama Islam

IAI Al-Qur'an Al-Ittifaqiah Indralaya

E-ISSN : 2774-7379

Qodir, Zuly. "Muhammadiyah Memperkuat Moderasi Islam Memutus Radikalisme.” Maarif 14, no. 2 (2019): 12-29.

Saleh, Sirajuddin. "Peran Lembaga Pendidikan Dalam Membentuk Karakter Bangsa." In Seminar Nasioonal Pendidikan Ilmu-Ilmu Sosial Membentuk Karakter Bangsa Dalam Rangka Daya Saing Global, 101-12. Makassar: HISPISI, 2016.

Shihab, M. Quraish. Wasathiyyah: Wawasan Islam Tentang Moderasi Beragama. I. Jakarta: Lentera Hati, 2019.

Sodiq, Ahmad. Prophetic Character Building. 1st ed. Jakarta: Kencana, 2018.

Sukring. "Kedudukan Pendidikan Agama (Islam) Dalam Undang-Undang No. 20 Tahun 2003 Tentang Sisdiknas." Jurnal Hukum “LEGITIME” III, no. 1 (2013).

Sutrisno, Edy. “Aktualisasi Moderasi Beragama Di Lembaga Pendidikan.” Jurnal Bimas Islam 12 , no. 1 (2019). 